\title{
Create Class Climate Effectively in Kindegarten
}

\author{
Rusdinal \\ Educational Administration Department \\ Education Faculty \\ Universitas Negeri Padang \\ Padang, Indonesia \\ rusdinalhar@yahoo.com
}

\author{
Hade Afriansyah \\ Educational Administration Department \\ Education Faculty \\ Universitas Negeri Padang \\ Padang, Indonesia \\ hadeafriansyah@,fip.unp.ac.id
}

\begin{abstract}
Classroom management for the kindergarten level needs to be done effectively. One of strategy for doing it by create climate class well. It is done to achieve the teaching objectives. Students will enjoy the learning process. All students difficulties are not buried alone. Students will feel free in the learning process. So, the strategy for create class climate at kindegarten effectively are: (1) Making the democracy atmosphere, (2) Developing the relationship between teacher and students, (3) Developing the relationship between students.
\end{abstract}

Keywords-classroom; climate; atmosphere; behavior; relationship

\section{INTRODUCTION}

Education is one of the basic social institutions of society. It is of great importance, and its ability to form and improve society is one of the main reasons it continues to be part of our culture. Children, as members (active or not) of society, must also be educated [1]. Classroom is a place where students interact with the teacher to carry out learning activities. Making learning activities in good quality requires a pleasant classroom, not so tense, active, and others. Creating a classroom atmosphere with such circumstances requires a proper classroom management strategy. One of them is by creating an effective classroom climate.

Classroom climate for every level of education isn't same. There are differences for each level, kindegarten one of them. The level of emotional development of children in kindergarten want a freedom and spontaneity in action, the child needs the help of the teacher in directing it. Children who are too restrained and silent will not be creative well.

Creating a conducive classroom climate can make children become more open and flexible so that the difficulties of children in learning are not buried children just like that. With the flexibility of children express opinions, express feelings and ask questions, to teachers and other friends, then the difficulty will not cause undesirable impact on the learning achievement of children. With the openness of children, the difficulties of the child is expected to be a way to achieve learning achievement successfully. Children who are not open with learning difficulties will always be left behind, while children who are open to learning difficulties and get proper help from the teacher will be able to achieve good learning progress.

Creating a classroom climate is a teacher's undertaking to create a harmonious class atmosphere and be free of distractions so that children feel safe and happy to learn. Jhonson and Bany [2] suggest that a good social climate within the class is emphasized in learning to live in cooperation with friends and facilitate positive emotional development. Same with Dreikurs and Cassel [2] emphasize that there are two important issues in classroom management, they are democratic classes and need to be notice the effects of certain effects (of an action or event) on behavior child.

Efforts to create a good classroom climate in addition to requiring effective linkage between teachers and children also emphasize the importance of good relationships between children and children. When children feel familiar with their friends, then they will want to help each other both in learning activities and in everyday social life.

A good classroom climate or classroom atmosphere is characterized by a good relationship. This will have an impact on the implementation when the teacher teaching and the significance and quality of the teaching and learning process undertaken. Therefore, the teacher's interaction with the child is necessary. Without interaction, it is difficult for teachers to create and maintain good classroom conditions. A good class climate depends on choice of strategies, methods and principles of work on teaching hours [3]

Creating a conducive classroom climate for children's learning activities in kindergartens can also be created through the teacher's efforts in applying his leadership. The pattern of leadership that is expected to be applied to children is a democratic pattern of leadership. Hurlock stated that educating children authoritatively, using punitive methods to strengthen strict adherence to children, will encourage unpleasant emotions to be dominant [4]. Conversely, how to educate children who are democratic will lead to a more relaxed atmosphere (relax) that will support the emotional expression of fun in children in learning.

All of the activity before, will support the activities of students in learning, because during the learning process, 
students get the coaching through democratic leadership and fell free of fear, anxiety, and depressed because of the familiarity between teachers with children and children with other children. This refers to Dreikurs and Cassel [2] that in the management of democratic atmosphere classes are a key element in classroom management. This democratic atmosphere is characterized by the role of the teacher as a facilitator and has a good personal relationship with the children and guides its development.

\section{RESULT AND DISCUSSION}

\section{A. Guidance of democratic atmosphere}

Guidance of democratic atmosphere is seen from the attitude of teachers who seek to show the role as a director and mentor in the learning process. Dreikurs and Cassel [2] argue that the democratic character of the teacher is to act as a guide and not a ruler, to speak in a friendly voice instead of a loud voice, using solicitation rather than order, using stimulus rather than coercion, offering suggestions rather than imposing ideas, controlling and not controlling, building courage rather than criticizing, helping and not punishing, broken-up responsibilities in groups rather than self-assertiveness.

Some of the activities of teachers in fostering a democratic atmosphere in the classroom that fits the above characteristics are child-friendly, guiding children by inviting children, building children's courage, helping children and solving responsibilities appropriately in children.

A friendly teacher speaks a bright face, smiles easily and speaks in a gentle voice, and does not offend the child and does not make the child depressed. So the impact on students is the child will be passionate to follow the learning, explore, not afraid to deal with the teacher, want to tell and ask him. Gordon states that one of the hallmarks of an ideal teacher is that the teacher is calm, never shouting, always good temperament, always calm, and never shows high emotion [5].

Every child does not have the same ability. Therefore, teachers need to give special attention to children with certain characters. The way that teachers can do is to guide children in play, learn to use invitations by offering children to tell stories, invite children to sing while embracing them and create situations for children to be accepted by their friends, by telling them what is well done and what is not good do.

Teachers can help by helping children in all their problems in learning such as helping a child get his stationery, sharpening his pencil, opening a drink tube, fetching a cake from his box, tidying his clothes, taking him to the toilet and so on.

In solving the responsibility of the child the teacher would have to pay attention first the level of independence of the child. Some examples of responsibilities that teachers can delegate to the classroom by the teacher are to ask the child to finish the job or tasks as well as possible, clean the blackboard, distribute books, collect books, keep the toys in place after use, cleaning and tidying up the place to eat, putting the garbage in its place, and so on.
The development of democratic atmosphere in the classroom needs to be continuously sought, maintained and developed by teachers as the democratic atmosphere is one of the main elements in effective classroom management. Dreikurs and Cassel [2] stated that the importance of a democratic classroom atmosphere to enable learners to be responsible and be treated as human beings who can make wise decisions in addition to being given the opportunity to bear the consequences of their own actions.

\section{B. Developing good relations of teachers and children}

Some of teacher activity that refers to developing good relationships between teachers and children are showing open attitudes, understanding child's difficulties, protecting children, warm attitude, and accepting children as they are. This is important for teachers to do the learning activities smoothly, errors, and difficulties that arise can be overcome easily. In the kindergarten, a teacher is in the position of an organizer, a person teaching much things [6].

Being open is an activity that is important enough done by the teacher to show the intimacy of the relationship with the child. Teachers can express the goodness of their students, express their pleasure when children are obedient, accepting children as they are by not discriminating against the child, teaching the child forward to dare to sing even if the child has not been good at singing, asking the child not to be afraid to come forward, which is positive.

Developing good relations of teachers and children need creativity. Creative learning which aims to overcome the psychological barriers of thinking, to develop ability to think abstractly, to build interaction of the teacher with the pupil on the basis of reflection, educational and creative selforganization for the intellectual and creative development [7].

Difficulties for students at Kindergarten is caused by the dependence of children who are marked by the child's behavior is childish or not in accordance with the behavior of children his age. In the face of such a child, the teacher should be able to reduce or even refuse the child's request to be helped continuously, so that children become easier to learn independently.

The child's emotional level at kindergarten is not the same as insecurity, fear, anxiety, and worry. Teachers should be able to demonstrate their attitude to protect children by persuading crying children, singing along with shy children when asked to sing to the front of the class, accompanying shy children sitting on their benches and forbidding children who insult their friends.

A warm attitude to the child is done by showing a sense of affection for the child. The affection given affects the child's natural development naturally and the child feels closer to the teacher. One of the teachers' actions that the teacher put affection on the child is by coming early to welcome the arrival of his students. The teacher can also give attention to the child and issue words that with the meaning of love to the child. 
Furthermore, the developing good relationships between teachers and children is to provide equal treatment to children and do not discriminate the ability of one child to another.

The closeness between the teacher and the child is very important, especially for children of kindergarten age who still need the closeness and affection of their parents. So it is not excessive if at Kindergarten need to delivered to the child that the teacher is a substitute for parents. It is intended that the creation of a warm relationship between the teacher with the child should as well as the relationship between children with their parents

\section{Developing good relationships of children and children}

The ability of teachers to develop good relationships between fellow children can support the creation of a conducive classroom climate for children in learning. Children who feel familiar with each other without any displeasure to friends will cause a calm and safe mood to learn so that the creation of better learning activities in children.

Homes and Load [8] stated that children feel a lot of difficulty and become less potential if they lose friends and encounter more difficulty in adjustment in school if they are short of friends or rejected by friends in his class. Hurlock also stated that the rejection or neglect of peers can cause negative influences in a child's life, such as feeling lonely, unhappy and man, developing an unpleasant self-concept that leads to personality deviation, lacking the learning experience needed to the process of socialization, feeling sad, trying to force themselves to enter the group and this will increase the group's resistance to them and further minimize their chances to learn various social skills, will live in uncertainty about social reactions to them and this will cause them to feel anxious, and highly sensitive, often excessive adjustments in the hope of improving their social acceptance [4].

The conditions above will affect the child in learning. For that the teacher should pay attention to the adjustment of the child because the teacher knows that a well-received child has a much greater possibility to work according to his or her ability than the child who is rejected or ignored by his classmates. Likewise, they are less likely to become vandals in the classroom and much less likely that they like to play truant than children who make poor adjustments.

Some activities to create a child's relationship with children is quite diverse and can be done in the learning process by creating a learning interaction. For example the teacher asks the child to complete the task in groups. This is a lot of benefits that can be taken by children such as the spirit of cooperation, mutual help, and responsibility and spur the learning outcomes of children for the better.

In addition, teachers can also instill an attitude of intimacy, help to help friends, tolerate others' circumstances, control emotions, accept friends as they are by taking away hatred, resentment and hostility between one child and another. The planting of these attitudes and behaviors can be done by teachers in the classroom or outside the classroom, in order to become a good daily habit and attached to the child. Thus the creation of a good relationship between the child with each other inside and outside the class ultimately supports the smooth learning activities in the classroom.

Bredekamp argues that children of child kindergarten are very concerned about friends, especially peers [9]. By paying attention to it properly teachers can foster good relationships with children and create a good relationship between children with children. This can have a positive effect on the child, that is to grow courage in the child.

For the creation of a conducive classroom climate for the child in learning, the intimacy of fellow-children is also necessary, as intimacy can reduce hate, resentment, and hostility between children. This condition strongly supports the creation of a peaceful and peaceful classroom climate so that children feel safe to learn and increasingly encourages their activities in learning, both individual and group learning.

Thus a good relationship between teacher and child, accompanied by the teacher's ability to create good relationships among fellow children is a conducive condition for learning. This fact shows that teachers are able to provide classroom management conditions that support student's learning activities.

\section{CONCLUSION}

The strategy for create class climate at kindegarten effectively are: (1) Making the democracy atmosphere through child-friendly, guiding children by inviting children, building children's courage, helping children and solving responsibilities appropriately in children, (2) Developing the relationship between teacher and students through showing open attitudes, understanding child's difficulties, protecting children, warm attitude, and accepting children as they are. This is important for teachers to do the learning activities smoothly, errors, and difficulties that arise can be overcome easily, (3) Developing the relationship between students.

\section{Acknowledgment}

The authors would like to thank Dean of Faculty of Education, Universitas Negeri Padang for support of this study.

\section{References}

[1] Z. Yonca and A. Demir, "A critical perspective on education through the concept of childhood," vol. 93, pp. 1030-1033, 2013.

[2] J. Hasibuan, Proses Belajar Mengajar; Keterampilan Dasar Mengajar Mikro. Bandung: Remaja Rosdakarya, 1994.

[3] B. Cvetkova, D. Andonovska-Trajkovska, and T. Atanasoska, "Values of some strategies of teaching and learning in fine art education," Procedia Soc. Behav. Sci., vol. 2, no. 2, pp. 2841-2845, 2010.

[4] E. B. Hurlock, Child Deelopment. 6th Edition. Jakarta: Erlangga, 1978.

[5] T. Gordon, Guru yang Efektif; Cara Mengatasi Kesulitan dalam Kelas. Jakarta: Rajawali, 1984.

[6] A. A. Arslan, "A Study into the Effects of Art Education on Children at the Socialisation Process," Procedia - Soc. Behav. Sci., vol. 116, pp. 4114-4118, 2014. 
[7] I. Lavrenteva, "New For rms and Methods s in the P edagogic c of Art: Creative e Int teraction $\mathrm{n}$ between $\mathrm{n}$ the Tea acher and d Childre," Procedia - Soc. Behav. Sci., vol. 146, pp. 405-409, 2014.

[8] B. Spodek, Handbook of Research on The Education Of Young Children. New York: McMillan Publishing Company, 1998.

[9] S. Bredekamp, Developmentally Appropriate Practice in Early Childhood Program Serving Children from Birth Through Age 8. Washington: NAEYC, 1987. 